\title{
Pengembangan Aplikasi Daring Pembelajaran IPA Pada Pokok Bahasan Organ Gerak Manusia
}

\author{
N. M. Anggi Dian Fitriani1*, I. Gst. A. Oka Negara ${ }^{2}$
}

${ }^{12}$ Program Studi Guru Sekolah Dasar, Universitas Pendidikan Ganesha, Singaraja, Indonesia

\section{A R T I C LE I N F O Article history: \\ Received 1 Januari 2021 Received in revised form 30 Januari 2021 Accepted 1 Maret 2021 Available online 8 April 2021}

\section{Kata Kunci:}

aplikasi, organ gerak manusia

Keywords: application, human movement organs

\begin{abstract}
A B S T R A K
Terbatasnya media pembelajaran elektronik yang dapat digunakan guru dalam proses pembelaran IPA mengakibatkan proses pembelajaran kurang interaktif. Penelitian ini bertujuan untuk menganalisis pengembangan aplikasi daring pembelajaran IPA pada pokok bahasan organ gerak manusia. Penelitian ini merupakan penelitian pengembangan dengan menggunakan model pengembangan ADDIE. Subjek penelitian ini adalah validitas aplikasi daring pembelajaran IPA pada pokok bahasan organ gerak manusia. Pengumpulan data menggunakan metode wawancara dan kuesioner. Analisis data yang digunakan adalah teknik analisis deskriptif kuantitatif dan deskriptif kualitatif. Hasil penelitian adalah menunjukkan aplikasi pembelajaran berada pada kualifikasi sangat baik dan tidak perlu direvisi $(96,6 \%)$, hasil review ahli desain pembelajaranberada pada kualifikasi sangat baik dan tidak perlu direvisi $(93,75 \%)$, hasil review ahli media pembelajaran berada pada kualifikasi sangat baik dan tidak perlu direvisi $(90 \%)$, hasil uji perorangan berada pada kualifikasi sangat baik dan tidak perlu direvisi $(90,53 \%)$, dan hasil uji kelompok kecil berada pada kualifikasi baik dan sedikit revisi
\end{abstract} (88,86\%). Berdasarkan hasil penelitian, dapat disimpulkan bahwa aplikasi pembelajaran IPA dinyatakan valid. Implikasi dari hasil penelitian ini yaitu meningkatkan semangat dan motivasi belajar siswa, membuka wawasan guru, dan menambah koleksi media pembelajaran di sekolah.

\begin{abstract}
A B S T R A C T
The limited electronic learning media that teachers can use in the science learning process results in the learning process being less interactive. This study aims to analyze the development of online science learning applications on the subject of human movement organs. This research is a development research using the ADDIE development model. The subject of this research is the validity of the online application of science learning on the subject of human movement organs. Collecting data using interviews and questionnaires. The data analysis used was descriptive quantitative and qualitative descriptive analysis techniques. The results showed that the learning application was in very good qualifications and did not need to be revised (96.6\%), the results of the learning design expert review were in very good qualifications and did not need to be revised (93.75\%), the results of the learning media expert reviews were at the qualification is very good and does not need to be revised (90\%), the individual test results are in very good qualifications and do not need to be revised (90.53\%), and the small group test results are in good qualifications and slightly revised (88.86\%). Based on the research results, it can be concluded that the science learning application is declared valid. The implications of the results of this study are increasing the enthusiasm and motivation of students to learn, opening teachers' insights, and increasing the collection of learning media in schools.
\end{abstract}

\section{Pendahuluan}

Proses pendidikan pada hakikatnya berfokus pada kegiatan belajar mengajar. Pembelajaran merupakan kegiatan terencana yang membuat dan merangsang seseorang untuk belajar, sehingga kegiatan pembelajaran mengacu kepada bagaimana seseorang mengalami perubahan tingkah laku melalui kegiatan belajar dan bagaimana melakukan kegiatan penyampaian informasi melalui kegiatan 
mengajar (Amelia \& Saputra, 2017; Krissandi \& Rusmawan, 2015; Mulyadin, 2016). Dalam mengajar guru harus mampu membimbing siswa dengan menyediakan situasi, kondisi, dan strategi pembelajaran yang tepat agar potensi yang dimiliki siswa dapat berkembang semaksimal mungkin. Proses pembelajaran beberapa bulan terakhir telah mengalami perubahan. Hal ini disebabkan oleh sebuah virus yang menyerang dunia, yaitu Covid-19 (Corona Virus Disease 2019). Covid -19 merupakan penyakit yang disebabkan oleh virus dan menyerang sistem pernapasan. Demi memutus rantai penyebaran Covid -19, sekolah-sekolah terpaksa ditutup. Meskipun sekolah ditutup, proses pembelajaran harus tetap berjalan. Surat edaran Menteri Pendidikan dan Kebudayaan menyatakan bahwa seluruh kegiatan pembelajaran dilakukan dengan sistem pembelajaran dalam jaringan (daring).

Pembelajaran daring merupakan pembelajaran jarak jauh melalui media internet dan alat penunjang seperti smartphoneatau telepon pintar dan laptop. Pada pembelajaran daring penggunaan teknologi semakin pesat. Kelebihan pembelajaran daring yaitu adanya keluwesan waktu dan tempat belajar, seperti belajar dapat dilakukan di kamar, di ruang tamu, dan sebagainya serta waktu yang disesuaikan, misalnya pagi, siang, sore, atau malam (Anugrahana, 2020; Fitriyani et al., 2020; Putria et al., 2020). Hal tersebut menuntut guru untuk meningkatkan kreativitasnya dalam pemanfaatan teknologi dan mendorong guru untuk selalu melakukan pengembangan dan pembaruan dalam pembelajaran. Pada pembelajaran daring siswa lebih sering mengunakan smartphone untuk belajar dan bermain game. Hal tersebut menjadi tantangan tersendiri bagi pembelajaran IPA untuk tetap memberikan siswa pemahaman konsep tentang mempelajari diri sendiri dan alam sekitar tetapi tetap bisa dilakukan dengan proses pembelajaran yang menyenangkan bagi siswa.

IPA merupakan salah satu pembelajaran yang dapat memberikan siswa akses untuk berkembang menjadi manusia yang memiliki kualitas serta mampu aktif dalam menjawab perkembangan zaman (Akbar, 2016; Mudanta et al., 2020; Qistina et al., 2019). Siswa diharapkan mendapat kesempatan yang besar untuk mengembangkan keterampilannya dengan melakukan berbagai kegiatan dalam pembelajaran IPA. Pembelajaran IPA dapat diterima dengan baik apabila siswa memiliki ketertarikan yang tinggi dalam proses pembelajaran. Salah satu cara yang dapat membuat pembelajaran IPA lebih menarik dan membuat pengalaman belajar siswa menjadi bermakna adalah dengan pengembangan media pembelajaran.

Pengembangan dapat diartikan sebagai suatu proses atau kegiatan yang dilakukan oleh seseorang untuk mengembangkan sesuatu agar menghasilkan produk yang lebih baik dan sempurna seperti media pembelajaran. Media pembelajaran merupakan sesuatu yang dapat digunakan untuk menyampaikan pesan dari guru kepada siswa, sehingga menimbulkan semangat, perhatian, dan minat belajar siswa (Irfan et al., 2019; Khosiyah \& Gunawan, 2019; Nurhadi \& Sobri, 2017). Metode dan media pembelajaran dapat dikatakan sebagai unsur yang tidak bisa dipisahkan karena memiliki fungsi untuk mengantarkan materi agar sampai kepada tujuan pembelajaran, sehingga media pembelajaran sebagai alat bantu memiliki peranan yang penting.

Hasil wawancara dengan guru Kelas V SD Negeri 11 Sumerta, kesulitan yang dirasa pada saat proses pembelajaran daring adalah siswa mudah jenuh dan sulit untuk fokus belajar karena belajar melalui smartphone. Guru menyatakan bahwa siswa membutuhkan media pembelajaran yang dapat memberikan siswa suasana baru agar dapat menarik minat dan semangat belajar siswa. Selain itu, guru kelas V SD Negeri 11 Sumerta lebih banyak menggunakan media pembelajaran yang sudah disediakan di sekolah dan belum pernah menggunakan media pembelajaran elektronik yang salah satunya adalah aplikasi pembelajaran karena kurangnya waktu serta pemahaman guru terhadap teknologi dalam mengembangkan media pembelajaran elektronik. Sedangkan pada saat pembelajaran daring dan perkembangan teknologi yang sangat pesat, seharusnya proses pembelajaran dapat dibantu dengan media pembelajaran elektronik agar pembelajaran menjadi interaktif. Berdasarkan kesenjangan tersebut, aplikasi pembelajaran penting dan sangat diperlukan untuk mendukung kegiatan pembelajaran terutama dalam pembelajaran daring agar menjadi lebih interaktif karena dapat memberikan suasana baru bagi siswa dan aplikasi pembelajaran yang bersifat mobile learning dapat memudahkan siswa dalam belajar dimana saja dan kapan saja. Media pembelajaran yang dapat dikembangkan pada pembelajaran daring dan dapat memberikan suasana baru bagi siswa salah satunya yaitu aplikasi pembelajaran.

Secara umum aplikasi adalah suatu perangkat yang siap dipakai oleh pengguna sebagai alat terapanyang memiliki fungsi khusus sesuai kemampuan yang dimiliki oleh aplikasi (Permana \& 
Nourmavita, 2017; Putri et al., 2016; Saifudin et al., 2020). Aplikasi dapat diartikan sebagai suatu program yang siap digunakan untuk melaksanakan suatu kegiatan atau fungsi bagi pengguna aplikasi serta penggunaan aplikasi lain yang dapat digunakan oleh suatu sasaran yang akan dituju.

Aplikasi pembelajaran dapat digunakan dalam pembelajaran IPA pada pokok bahasan organ gerak manusia, karena materi tersebut tidak bisa dipelajari hanya dengan membaca materi saja. Pada saat pembelajaran tatap muka atau pembelajaran luar jaringan (luring), guru biasanya akan memberikan media rangka manusia yang sudah tersedia di sekolah sebagai media pembelajarannya. Tetapi pada pembelajaran daring, media rangka manusia tersebut kurang efektif untuk digunakan. Media rangka manusia hanya bisa digunakan pada saat pembelajaran tatap muka saja, karena sifat media tersebut tidak bisa digunakan dimana saja. Berbeda dengan aplikasi pembelajaran yang bersifat mobile. Mobile learning merupakan salah satu alternatif pengembangan media pembelajaran (Nurhadi \& Sobri, 2017; Putria et al., 2020; Widayat et al., 2014).

Mobile learning dapat dijadikan sebagai alternatif dalam menangani permasalahan pembelajaran karena sifat kepraktisan dari mobile learningbagian dari pembelajaran elektronik atau e-learning yang merupakan pemanfaatan media pendidikan jarak jauh. Mobile learning memberikan konten dan sumber materi pembelajaran yang dapat dimuat dalam perangkat saku seperti smartphone, PDA, tablet, i-pad, mobile phone, dan perangkat sejenis (Irfan et al., 2019; Ningsih \& Adesti, 2019; Nurseto, 2011).

Pengembangan media pembelajaran dalam bentuk mobile learning mampu memenuhi kriteria tujuan dan isi pembelajaran, sesuai dengan karakteristik siswa, hemat waktu pembelajaran, dan mudah digunakan oleh siswa. Kelebihan media daring mobile learning adalah dapat menyajikan sistem pembelajaran yang bisa dilaksanakan dengan jarak jauh, dimanapun, dan kapanpun serta dapat menarik perhatian siswa terhadap materi pembelajaran yang akan membuat proses pembelajaran menjadi lebih aktif (Amrita \& Kuswanto, 2019; Baharuddin et al., 2017; Putra, 2017). Sifat aplikasi pembelajaran yang mobile dapat memudahkan siswa mengakses melalui smartphone.

Smartphone dan internet bukan lagi menjadi musuh siswa, tetapi bisa menjadi teman bagi siswa. Siswa dapat membatasi penggunaan smartphone itu dari kesadaran diri sendiri, pengaruh teman, didikan orangtua, dan juga guru-guru di sekolah (Astuti et al., 2017; Egok \& Hajani, 2018; Hanafy, 2014). Penggunaan smartphone pada siswa bisa diarahkan kepada hal-hal yang positif dengan pengawasan orang tua di rumah, disinilah peran sebagai orang tua dibutuhkan untuk dapat membimbing dan mengarahkan anaknya agar tidak kehilangan kontrol dirinya (Khosiyah \& Gunawan, 2019; Ningsih \& Adesti, 2019; Surahman, 2019).

Aplikasi media pembelajaran daring berupa mobile learningyang dapat diakses melalui smartphone termasuk dalam multimedia interaktif. Pengembangan aplikasi pembelajaran juga didasari pada kajian hasil penelitian yang relevan seperti penelitian yang dilakukan oleh (Widayat et al., 2014) dalam penelitian tentang pengembangan multimedia interaktif sebagai media pembelajaran IPA terpadu pada tema sistem gerak pada manusia. Hasil dari penelitiannya adalah multi media pembelajaran interaktif tentang sistem gerak pada manusia yang dikembangkan dinilai layak digunakan sebagai media pembelajaran dan dapat membantu meningkatkan hasil belajar siswa dengan pencapaian 100\% ketuntasan klasikal. Selain itu, penelitian yang dilakukan oleh (Egok \& Hajani, 2018) dalam penelitian tentang pengembangan multimedia interaktif pada pembelajaran IPA bagi siswa sekolah dasar kota Lubuklinggau. Hasil dari penelitiannya adalah multimedia interaktif yang dikembangkan layak untuk digunakan dalam proses pembelajaran IPA dan terdapat efek potensial yang positif terhadap hasil belajar siswa. Dan penelitian yang dilakukan oleh (Permana \& Nourmavita, 2017) dalam penelitian tentang pengembangan multimedia interaktif pada mata pelajaran IPA materi mendeskripsikan daur hidup hewan di lingkungan sekitar siswa kelas IV sekolah dasar. Hasil dari penelitiannya adalah guru dan siswa memberi respon positif terhadap media yang ditunjukan sehingga dapat dikatakan bahwa siswa sangat menyukai media tersebut dan berdasarkan penilaian para ahli menunjukan bahwa media sangat layak dijadikan media pembelajaran IPA untuk siswa kelas IV sekolah dasar.

Tujuan penelitian ini adalah menganalisis pengembangan aplikasi daring pembelajaran IPA pada pokok bahasan organ gerak manusia kelas V Sekolah Dasar berdasarkan hasil evaluasi para ahli, uji coba perorangan, dan uji coba kelompok kecil. 


\section{Metode}

Jenis penelitian ini adalah penelitian pengembangan. Dalam penelitian ini peneliti menggunakan model pengembangan ADDIE. Model ADDIE melibatkan lima tahap yang meliputi tahap analisis, tahap desain, tahap pengembangan, tahap implementasi, dan tahap evaluasi. Model ADDIE lebih tepat digunakan untuk pengembangan media pembelajaran berbasis software sehingga dapat dikembangkan secara sistematis. Model ADDIE merupakan model yang dibuat secara terprogram dan memiliki urutan kegiatan yang sistematis sebagai bentuk pemecahan masalah belajar dan berkaitan dengan sumber belajar yang sesuai dengan kebutuhan, kondisi, dan karakteristik siswa.

Prosedur penelitian yang digunakan dalam pengembangan media pembelajaran ini adalah sebagai berikut: (1) Tahap analisis yang meliputi analisis kesenjangan, analisis kebutuhan siswa, analisis kompetensi dasar, dan analisis isi aplikasi pembelajaran; (2) Tahap Desain yang meliputi tahap pengumpulan data, perancangan algoritma, membuat story board, menyusun instrumen validasi produk, dan menyusun RPP; (3) Tahap pengembangan yang melibatkan penggunaan Microsoft Office Power Point, Ispring, dan aplikasi website 2 apk. Kemudian melakukan tahap review dari ahli isi, ahli desain, dan ahli media pembelajaran;(4) Tahap implementasi meliputi tahap uji coba perorangan dan uji coba kelompok kecil. Uji lapangan dan uji efektivitas tidak dapat dilakukan karena dalam situasi pandemi Covid-19; (5) Tahap evaluasi yang dilakukan pada setiap tahapan pada penelitian pengembangan model ADDIE.

Subjek penelitian ini adalah validitas aplikasi daring pembelajaran IPA pada pokok bahasan organ gerak manusia. Pengembangan aplikasi pembelajaran IPA pada pokok bahasan organ gerak manusia kelas V Sekolah Dasar ini harus diuji tingkat validitasnya berdasarkan hasil analisis kegiatan uji coba yang dilaksanakan melalui tahap review ahli isi pembelajaran, ahli desain pembelajaran, ahli media pembelajaran, uji coba perorangan, dan uji coba kelompok kecil. Ahli isi dalam penelitian pengembangan ini adalah dosen yang memiliki kualifikasi dibidang IPA. Ahli desain pembelajaran dan ahli media pembelajaran yaitu dosen yang memiliki kualifikasi dibidang teknologi pendidikan. Uji coba perorangan yaitu 3 orang siswa kelas $\mathrm{V}$ yang memiliki prestasi belajar tinggi, sedang, dan rendah. Subjek uji coba kelompok kecil yaitu9 orang siswa yang terdiri atas 3 orang berprestasi belajar tinggi, 3 orang berprestasi belajar sedang, dan 3 orang berprestasi belajar rendah.

Pengumpulan data dalam penelitian ini menggunakan metode wawancara dan kuesioner. Dalam penelitian ini, kuesioner digunakan untuk mengumpulkan data hasil review dari para ahli dan subjek uji coba. Instrumen penelitian berupa kuesioner dirancang menggunakan skala 4 dengan ketentuan "Sangat Setuju (4), Setuju (3), Tidak Setuju (2), dan Sangat Tidak Setuju (1)”. Instrumen pengumpulan data untuk ahli isi pembelajaran, ahi desain pembelajaran, ahli media pembelajaran, uji coba perorangan, dan uji coba kelompok kecil, sebelum digunakan harus diuji dulu kualitasnya oleh dosen pembimbing dengan memvalidasi secara logis. Kisi-kisi instrumen kuesioner yang digunakan dapat dilihat pada Tabel 1.

Tabel 1. Kisi-kisi Kuesioner

\section{Indikator Kuesioner}

\begin{tabular}{|c|c|c|c|}
\hline $\begin{array}{c}\text { Ahli Isi } \\
\text { Pembelajaran } \\
\end{array}$ & $\begin{array}{c}\text { Ahli Desain } \\
\text { Pembelajaran }\end{array}$ & $\begin{array}{c}\text { Ahli Media } \\
\text { Pembelajaran }\end{array}$ & $\begin{array}{l}\text { Uji Coba Perorangan } \\
\text { dan Kelompok kecil }\end{array}$ \\
\hline $\begin{array}{l}\text { Kesesuaian materi } \\
\text { dengan kompetensi } \\
\text { dasar dan indikator }\end{array}$ & $\begin{array}{l}\text { Kejelasan tujuan } \\
\text { pembelajaran }\end{array}$ & $\begin{array}{l}\text { Kualitas } \\
\text { tampilan }\end{array}$ & Kualitas tampilan \\
\hline Kesesuaian isi materi & $\begin{array}{l}\text { Kesesuaian strategi } \\
\text { penyampaian dengan } \\
\text { karakteristik siswa }\end{array}$ & $\begin{array}{l}\text { Tata letak } \\
\text { tombol }\end{array}$ & Tata letak tombol \\
\hline Kelengkapan materi & $\begin{array}{l}\text { Ketepatan strategi } \\
\text { penyampaian } \\
\text { memberikan dampak } \\
\text { bagi siswa }\end{array}$ & Kualias teks & Kualias teks \\
\hline $\begin{array}{l}\text { Keruntutan materi } \\
\text { Bahasa mudah }\end{array}$ & $\begin{array}{l}\text { Kualitas memotivasi } \\
\text { Kejelasan petunjuk }\end{array}$ & $\begin{array}{l}\text { Kualitas gambar } \\
\text { Kualitas video }\end{array}$ & $\begin{array}{l}\text { Kualitas gambar } \\
\text { Kualitas video }\end{array}$ \\
\hline
\end{tabular}




\begin{tabular}{|c|c|c|c|}
\hline $\begin{array}{c}\text { Ahli Isi } \\
\text { Pembelajaran }\end{array}$ & $\begin{array}{c}\text { Ahli Desain } \\
\text { Pembelajaran }\end{array}$ & $\begin{array}{c}\text { Ahli Media } \\
\text { Pembelajaran }\end{array}$ & $\begin{array}{l}\text { Uji Coba Perorangan } \\
\text { dan Kelompok kecil }\end{array}$ \\
\hline $\begin{array}{l}\text { dimengerti } \\
\text { Kualitas soal } \\
\text { Keseimbangan } \\
\text { proporsi soal dengan } \\
\text { materi }\end{array}$ & $\begin{array}{l}\text { pengerjaan soal } \\
\text { Kualitas soal }\end{array}$ & $\begin{array}{l}\text { Kualitas audio } \\
\text { Kemudahan } \\
\text { dalam } \\
\text { pengoperasian } \\
\text { Kelancaran } \\
\text { dalam } \\
\text { pengoperasian } \\
\text { Keterbaharuan } \\
\text { media }\end{array}$ & $\begin{array}{l}\text { Kualitas audio } \\
\text { Isi materi } \\
\text { Kemudahan } \\
\text { pemahaman } \\
\text { Kemudahan } \\
\text { pengoperasian } \\
\text { Bahasa mudah } \\
\text { dipahami }\end{array}$ \\
\hline
\end{tabular}

Teknik analisis data dalam penelitian pengembangan ini menggunakan analisis deskriptif kuantitatif dan analisis deskriptif kualitatif. Teknik analisis deskriptif kuantitatif digunakan untuk mengolah skor perolehan dari masing-masing kuesioner yang diisi oleh para ahli dan siswa. Sedangkan teknik analisis deskriptif kualitatif digunakan untuk mengolah data berupa pernyataan sangat setuju (SS), setuju (S), tidak setuju (TS), dan sangat tidak setuju (STS), serta saran dan masukan yang terdapat pada kuesioner para ahli dan siswa.

\section{Hasil dan Pembahasan}

Rancang bangun aplikasi pembelajaran menggunakan model pengembangan ADDIE yang terdiri dari lima tahap. Tahap awal dalam mengembangkan aplikasi pembelajaran adalah tahap analisis yang dilakukan melalui wawancara dengan guru kelas V SD Negeri 11 Sumerta yang terdiri dari analisis kesenjangan, analisis kebutuhan siswa, analisis kompetensi dasar, dan analisis isi aplikasi pembelajaran. Hasil dari analisis kesenjangan yaitu guru lebih sering menggunakan media yang sudah disediakan di sekolah sehingga pada saat pembelajaran daring belum ada media pembelajaran elektronik seperti aplikasi pembelajaran yang dapat mendukung prose pembelajaran. Hasil dari analisis kebutuhan siswa adalah siswa membutuhkan suasana baru agar pembelajaran bisa lebih bermakna bagi siswa dan aplikasi pembelajaran bisa memberikan suasana baru bagi siswa.Hasil dari analisis kompetensi dasar adalah merancang indikator dan tujuan pembelajaran sesuai dengan kompetensi dasar atau kompetensi yang dituntut tercapai pada siswa.Hasil dari analisis isi aplikasi pembelajaran adalah pembelajaran IPA pada pokok bahasan organ gerak manusia kelas V sekolah dasar mencakup materi rangka, otot, kelainan pada tulang, dan kelainan pada otot.

Tahap kedua dalam mengembangkan aplikasi pembelajaran yaitu tahap desain. Ada 3 proses pada tahap desain inidiantaranya: (1) Tahap pengumpulan data yaitu mengumpulkan materi, gambar, dan video yang terkait dalam pembuatan aplikasi pembelajaran. (2) Perancanganalgoritma dalam bentuk flowchart yang merupakan merupakan gambaran alur jalannya suatu program agar mudah dimengerti. (3) Membuat storyboard yang merupakan runtutan gambar yang disusun secara sistematis dan menggambarkan setiap rancangan tampilan dari masing-masing interface sebuah aplikasi pembelajaran.

Tahap ketiga adalah tahap pengembangan. Kegiatan pada tahap pengembangan ini meliputi tahapan membuat materi menggunakan Microsoft Office Power Point dengan memanfaatkan fasilitas hyperlink, menonaktifkan on mouse click dan semua tombol pada slidepower point, membuat evaluasi materi menggunakan Ispring, mengunggah materi menggunakan Ispring, mengubah file materi power point menjadi aplikasi menggunakan aplikasi website 2 apk, dan mengunduh aplikasi pembelajaran pada smartphone. Setelah produk selesai dikembangkan, selanjutnya aplikasi pembelajaran divalidasi oleh para ahli diantaranya: ahli isi pembelajaran, ahli desain pembelajaran, dan ahli media pembelajaran.

Tahap keempat merupakan tahap implementasi yang meliputi uji coba perorangan dan uji coba kelompok kecil. Uji coba lapangan yang juga juga menguji efektivitas dari produk aplikasi 
pembelajaran. tidak dapat dilakukan karena dalam situasi pandemi Covid-19. Tahap kelima adalah tahap evaluasi yang dilakukan pada setiap tahapan pada penelitian pengembangan model ADDIE. Hal ini terkait dengan kelemahan dan kekurangan yang ada pada aplikasi pembelajaran yang nantinya dapat menyempurnakan aplikasi pembelajaran. Validitas pengembangan aplikasi pembelajaran berdasarkan uji ahli isi pembelajaran yang dilakukan oleh dosen yang memiliki kualifikasi pendidikan di bidang IPA yaitu Drs. Ida Bagus Surya Manuaba, S.Pd., M.For. Berdasarkan hasil penilaian, persentase yang diperoleh yaitu $96,6 \%$ yang berada pada kualifikasi sangat baik dan tidak perlu direvisi serta tidak terdapat saran dan masukan yang diberikan. Uji ahli desain pembelajaran dilakukan oleh salah satu dosen pengajar di Program Studi Teknologi Pendidikan FIP Undiksha yaitu Dr. I Kadek Suartama, S.Pd., M.Pd. Berdasarkan hasil penilaian, persentase yang diperoleh yaitu 93,75\% yang berada pada kualifikasi sangat baik dan tidak perlu direvisi serta tidak terdapat saran dan masukan yang diberikan. Uji ahli media pembelajaran dilakukan oleh Dr. I Kadek Suartama, S.Pd., M.Pd. Berdasarkan hasil penilaian, persentase yang diperoleh yaitu 90\% yang berada pada kualifikasi sangat baik dan tidak perlu direvisi. Saran dan masukan yang diberikan yaitu tambahkan petunjuk belajar dan tambahkan sasaran program pada judul.

Aplikasi pembelajaran telah melewati tahap review dari para ahli dan telah direvisi sesuai dengan saran dan masukan dari para ahli selanjutnya diuji cobakan kepada 3 orang siswa kelas V SD Negeri 11 Sumerta. Berdasarkan hasil penilaian, didapatkan hasil persentase 90,53\% yang berada pada kualifikasi sangat baik dan tidak perlu revisi. Adapun saran dan masukan yang diberikan yaitu aplikasi sangat menarik tetapi masih ada lagu, aplikasi menarik bagus sangat mudah untuk dicerna atau dipelajari, dan aplikasi pembelajaran mudah digunakan, kualitas gambar baik, video dapat terlihat dengan jelas. Setelah uji coba perorangan dilakukan uji coba kelompok kecil. Uji coba kelompok kecil dilakukan oleh 9 orang siswa kelas V SD Negeri 11 Sumerta.

Berdasarkan hasil penilaian, didapatkan hasil persentase $88,86 \%$ yang berada pada kualifikasi baik dan sedikit revisi. Adapun saran dan masukan yang diberikan yaituaplikasi sangat menarik tetapi lagu yang dimainkan sangat mengganggu, aplikasinya sangat menarik membuat semangat belajar, dan aplikasi membuat semangat belajar.

Tabel 2. Persentase Hasil Validitas Pengembangan Aplikasi Pembelajaran

\begin{tabular}{cccc}
\hline Subjek Uji Coba & Hasil Validitas (\%) & Kualifikasi & Keterangan \\
\hline Uji Ahli Isi Pembelajaran & 96,6 & Sangat Baik & Tidak Perlu Direvisi \\
Uji Ahli Desain Pembelajaran & 93,75 & Sangat Baik & Tidak Perlu Direvisi \\
Uji Ahli Media Pembelajaran & 90 & Sangat Baik & Tidak Perlu Direvisi \\
Uji Coba Perorangan & 90,53 & Sangat Baik & Tidak Perlu Direvisi \\
Uji Coba Kelompok Kecil & 88,86 & Baik & Sedikit Revisi \\
\hline
\end{tabular}

Revisi produk dilakukan setelah produk dinilai kelayakannya oleh para ahli dan siswa. Saran dan masukan yang berkaitan dengan kualitas aplikasi pembelajaran dapat dijadikan pertimbangan untuk lebih menyempurnakan aplikasi pembelajaran. Berdasarkan pemaparan analisis hasil validitas pengambangan aplikasi pembelajaran, terdapat saran dan masukan yang diberikan oleh ahli media pembelajaran dan siswa. Saran dan masukan dari ahli media pembelajaran yaitu tambahkan petunjuk belajar dan tambahkan sasaran program pada judul. Saran dan masukan yang diberikan oleh siswa tidak ada yang bersifat revisi walaupun terdapat saran dan masukan terkait musik audio yang mengganggu, tetapi tidak ada revisi yang perlu dilakukan karena jawaban dari saran yang diberikan siswa sudah terdapat dalam aplikasi pembelajaran yaitu jika tidak ingin memutar audio maka pada halaman utama pada ikon audio tidak perlu disentuh dan begitu pula sebaliknya serta pada petunjuk belajar sudah ditekankan bahwa apabila musik volume audio terlalu keras dan mengganggu maka bisa menggunakan fitur pada perangkat masing-masing untuk mengecilkan volume audio. Sehingga tidak ada saran yang sifatnya revisi walaupun berada pada kriteria baik dan sedikit revisi. Berdasarkan hal tersebut, maka revisi produk dilakukan berdasarkan saran dan masukan dari ahli media pembelajaran saja. Tampilan aplikasi sebelum dan sesudah direvisi oleh peneliti sesuai saran dan masukan ahli media pembelajaran dapat dilihat pada Gambar 1 dan Gambar 2. 


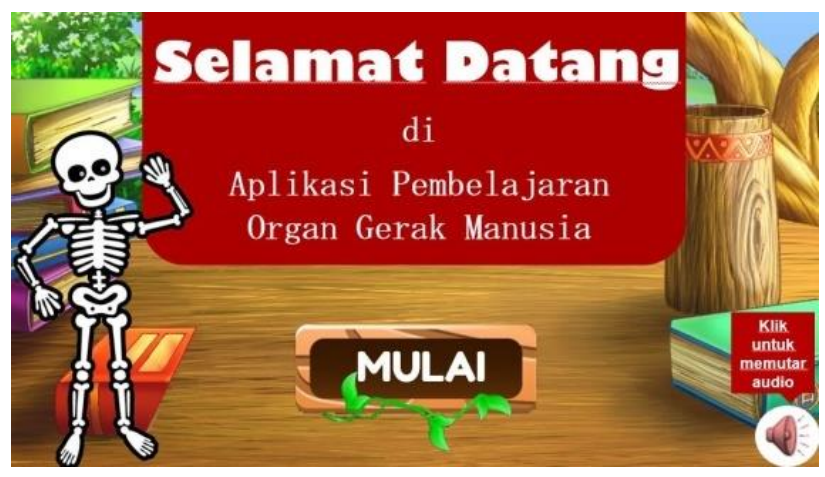

Gambar 1. Sebelum revisi

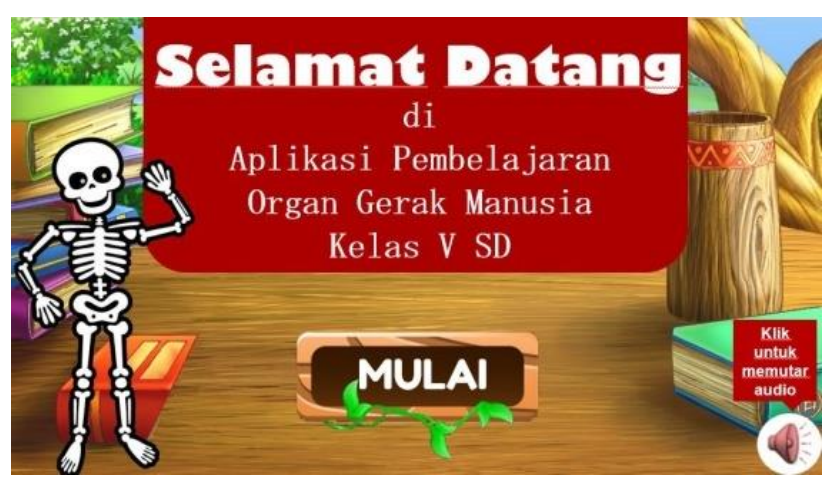

Gambar 2. Setelah Revisi

Pengembangan aplikasi pembelajaran menggunakan model penelitian ADDIE. Pemilihan model ADDIE didasarkan atas pertimbangan bahwa model ini lebih tepat digunakan untuk pengembangan media pembelajaran berbasis software sehingga dapat dikembangkan secara sistematis. Validitas aplikasi pembelajaran ini ditentukan berdasarkan hasil evaluasi dari ahli meliputi ahli isi pembelajaran, ahli desain pembelajaran, ahli media pembelajaran. Dan dari uji coba siswa meliputi uji coba perorangan dan uji coba kelompok kecil.

Berdasarkan hasil review dari ahli isi pembelajaran IPA, diketahui bahwa aplikasi pembelajaran berada pada kualifikasi sangat baik. Hal tersebut bermakna penyajian materi dalam aplikasi pembelajaran sudah sesuai dengan kompetensi dasar, materi sudah sesuai dengan indikator, materi sudah sesuai dengan perkembangan kognitif siswa, materi sudah bebas dari kesalahan konsep, materi tepat digunakan untuk siswa kelas V, cakupan materi sudah luas, materi sudah disajikan secara lengkap, dan materi sudah disajikan secara runtut. Isi materi dalam aplikasi pembelajaran sangat penting disesuaikan dengan kompetensi dasar dan indikator agar siswa mendapat materi yang mampu membantu siswa meraih kompetensi yang harus dicapai, karena perumusan materi dalam media pembelajaran haruslah berkaitan dengan substansi isi pembelajaran yang harus diberikan dan berisi materi yang harus dikuasai siswa. Jika dilihat dari aspek kebahasaan, ahli isi menyatakan bahwa aplikasi pembelajaran sudah menggunakan bahasa yang mudah untuk dimengerti, sudah menggunakan kalimat yang komunikatif, bahasa yang digunakan sudah tidak bermakna ganda, dan sudah menggunakan bahasa yang sesuai dengan penguasaan siswa. Dan jika dilihat dari aspek evaluasi, ahli isi menyatakan bahwa aplikasi pembelajaran sudah menggunakan soal evaluasi yang sesuai dengan tujuan pembelajaran, soal evaluasi sudah dapat dikatakan mampu membantu siswa dalam memahami materi pembelajaran, dan proporsi soal dengan materi sudah seimbang. Hal ini sejalan dengan (Darmawan, 2014; Diawati, 2018; Mudarini, 2017), yang menyatakan bahwa pembelajaran merupakan kegiatan yang menjabarkan kompetensi dasar serta teori pokok yang memuat indikator pencapaian hasil belajar dalam setiap pokok bahasan.

Berdasarkan hasil review dari ahli desain pembelajaran, diketahui bahwa aplikasi pembelajaran berada pada kualifikasi sangat baik. Hal tersebut bermakna tujuan pembelajaran sudah sesuai dengan indikator, strategi penyampaian materi dalam aplikasi pembelajaran sudah sesuai dengan karakteristik siswa, strategi penyampaian materi sudah tepat sehingga memungkinkan kemudahan pemahaman materi dan memungkinkan kecepatan penguasaan materi bagi siswa, serta penyajian materi sudah mampu mendorong motivasi belajar dan mendorong kemampuan menalar siswa. Dan jika dilihat dari aspek evaluasi, menurut ahli desain petunjuk pengerjaan soal evaluasi dalam aplikasi pembelajaran mudah dipahami dan soal evaluasi sudah sesuai dengan tujuan pembelajaran. Mengetahui karakteristik siswa terlebih dahulu merupakan bagian penting dalam mendesain pembelajaran agar terjadi proses pembelajaran yang menyenangkan. Perancangan media didasarkan atas kebutuhan dan salah satu indikator adanya kebutuhan yaitu karakteristik siswa (Citrasmi et al., 2016; Londa et al., 2018; Widiana et al., 2019).

Hasil review dari ahli media pembelajaran, diketahui bahwa aplikasi pembelajaran berada pada kualifikasi sangat baik. Hal tersebut bermakna tema yang digunakan dalam aplikasi pembelajaran menarik, desain tampilan sudah sesuai dengan karakteristik siswa, desain tampilan dapat menarik minat siswa, kombinasi warna yang digunakan sudah bagus sehingga terlihat menarik, posisi tata letak tombol sudah diatur dengan tepat, ukuran tombol sudah diatur dengan tepat, setiap tombol dapat 
dioperasikan dengan lancar, teks dapat dibaca dengan baik, jenis font sudah diatur dengan tepat, ukuran font sudah tepat, warna teks sudah kontras dengan warna latar, kualitas gambar baik, gambar sudah sesuai dengan materi, video dapat terlihat dengan jelas, dan backsound yang digunakan sudah sesuai.Jika dilihat dari aspek pengoperasian, ahli media menyatakan bahwa aplikasi pembelajaran sangat mudah untuk diunduh, mudah dioperasikan, tidak berat saat dijalankan, dan tidak berhenti saat dijalankan.Dan jika dilihat dari aspek pembaharuan media, menurut ahli desain aplikasi pembelajaran termasuk dalam media pembelajaran yang sangat up to date.Hasil ini sejalan dengan hasil penelitian dari (Permana \& Nourmavita, 2017; Putri et al., 2016; Saifudin et al., 2020) tentang perancangan aplikasi perangkat ajar pengenalan anggota tubuh manusia berbasis android, yang menyatakan bahwa desain yang sederhana dapat membuat siswa tidak bingung, media mudah dioperasikan oleh siswa karena dirancang untuk mudah digunakan, sistem dapat menjelaskan tentang materi dengan jelas sehingga siswa dapat lebih mudah dalam mempelajari materi.

Aspek pengoperasian merupakan bagian yang penting bagi siswa pada saat menjalankan aplikasi pembelajaran, karena jika aplikasi pembelajaran secara tiba-tiba berhenti saat dijalankan maka hal tersebut akan mengganggu fokus belajar siswa. Desain tampilan, kombinasi warna, tata letak tombol, jenis font, gambar, video, dan audio sangat penting untuk disesuaikan dengan karakteristik siswa agar dapat menarik minat belajar siswa terhadap aplikasi pembelajaran. Gambar dan video dikhususkan untuk memperjelas suatu keadaan karena dapat menunjukkan situasi yang nyata kepada siswa, sehingga gambar dan video akan membuat siswa lebih mudah untuk mengingat dan mengerti materi yang disajikan. Gambar dan video yang disertakan haruslah relevan dengan materi yang disajikan karena akan mempengaruhi kejelasan pesan dalam materi yang disajikan dalam sebuah media pembelajaran. Materi yang disajikan dengan gambar memberikan kemudahan siswa memahami suatu konsep sehingga tidak salah persepsi dan materi menjadi mudah untuk diingat (Nurhadi \& Sobri, 2017; Putria et al., 2020; Widayat et al., 2014).

Aplikasi pembelajaran telah melewati review para ahli, kemudian aplikasi pembelajaran dapat diujicobakan kepada siswa. Aplikasi pembelajaran pada tahap uji coba perorangan berada pada kualifikasi sangat baik dan pada tahap uji coba kelompok kecil berada pada kualifikasi baik.Hal tersebut bermakna desain aplikasi pembelajaran menarik seperti tema aplikasi pembelajaran, kombinasi warna yang digunakan, tata letak tombol, jenis fonttulisan, penyajian gambar, penyajian video, dan penyajian audio diatur dan ditata dengan tepat sehingga menjadi suatu aplikasi pembelajaran yang memiliki desain yang menarik sehingga dapat membuat siswa tertarik dalam menggunakan aplikasi pembelajaran. Adanya penjelasan materi berupa teks ditambah dengan penyajian gambar dan video dalam satu slide materi merupakan hal yang membuat siswa semakin antusias untuk belajar karena sangat membantu siswa untuk menginterpretasikan pesan yang disampaikan dalam teks materi. Gambar dan video memberikan kejelasan kejadian yang terjadi yang tidak bisa dijelaskan hanya melalui pesan teks sehingga gambar dan video digunakan untuk menunjang keefektifan aplikasi pembelajaran. Melibatkan berbagai indera dalam pembelajaran membuat siswa lebih mudah dalam mendapat ilmu (Amrita \& Kuswanto, 2019; Baharuddin et al., 2017; Putra, 2017). Jika dilihat dari aspek materi, menurut siswa aplikasi pembelajaran sudah menyajikan materi secara lengkap, secara runtut, dan mudah dipahami. Kemudian jika dilihat dari aspek pengoperasian, menurut siswa aplikasi pembelajaran mudah dijalankan, tidak berat saat dijalankan, dan tidak berhenti saat dijalankan. Dan jika dilihat dari aspek evaluasi, siswa menyatakan bahwa kalimat soal evaluasi yang digunakan dalam aplikasi pembelajaran mudah dipahami oleh siswa.

Penelitian dari (Qistina et al., 2019) tentang pengembangan multi media interaktif mata pelajaran IPAkelas IV SD, menyatakan bahwa multi media interaktif mendapatkan hasil validitas yang tinggi menunjukan bahwa media tersebut efektif karena membuat siswa termotivasi dalam belajar. Hasil penelitian lain datang dari (Nurhadi \& Sobri, 2017) tentang pengembangan media pembelajaran IPA berbasis android dalam meningkatan kwalitas pembelajaran siswa, yang menyatakan bahwa aplikasi pembelajaran yang dihasilkan dapat menjadikan media pembelajaran tambahan dalam pembelajaran selain buku siswa. Sama halnya dengan penelitian dari (Saifudin et al., 2020) tentang pengembangan multimedia interaktif materi sumber energi untukmemudahkanbelajar siswa SD, yang menunjukan bahwa multimedia interaktif memiliki kedudukan sebagai tambahan yang bisa digunakan di dalam maupun di luar sekolah yang dapat meningkatkan pemahaman siswa terkait materi dan membuat siswa tidak mudah jenuh. Hal tersebut sejalan dengan penelitian dari (Akbar, 2016) tentang pengembangan multimedia interaktif IPA berorientasi guided inquiry pada materi sistem pernapasan 
manusia kelas V SD, yang menyatakan bahwa multimedia interaktif dinyatakan sangat layak, dapat diimplementasikan dalam pembelajaran, serta dinyatakan sangat praktis, menarik, dan efektif. Berdasarkan hasil penelitian tersebut, maka aplikasi pembelajaran yang termasuk dalam multimedia interaktif mendapat nilai validasi yang tinggi menunjukan bahwa media tersebut layak diimplementasikan dalam proses pembelajaran dan juga dapat menjadi tambahan pembelajaran di dalam dan di luar sekolah karena sangat praktis, menarik, dan efektif.

Implikasi dari hasil penelitian ini yaitu tampilan aplikasi pembelajaran yang menarik mampu meningkatkan semangat dan motivasi belajar siswa karena kombinasi warna yang tepat dan pemaparan materi yang disertakan dengan gambar dan video membuat siswa tidak jenuh dalam belajar, membuka wawasan guru yang diharapkan tidak terlalu terpaku pada media pembelajaran konvensional dan mulai memanfaatkan teknologi dalam pembuatan media pembelajaran mengingat kemajuan dan perkembangan teknologi yang sangat pesat dalam bidang pendidikan, dan penelitian ini memberi manfaat kepada sekolah karena memiliki koleksi media pembelajaran elektronik berupa aplikasi pembelajaran IPA pada pokok bahasan organ gerak manusia kelas V SD.

\section{Simpulan}

Aplikasi daring pembelajaran IPA pada pokok bahasan organ gerak manusia dinyatakan valid berdasarkan hasil review ahli isi pembelajaran, ahli desain pembelajaran, ahli media pembelajaran, uji coba perorangan, dan uji coba kelompok kecil. Implikasi dari hasil penelitian ini yaitu meningkatkan semangat dan motivasi belajar siswa, membuka wawasan guru, dan menambah koleksi media pembelajaran di sekolah.

\section{Daftar Pustaka}

Akbar, T. N. (2016). Pengembangan Multimedia Interaktif IPA Berorientasi Guided Inquiry pada Materi Sstem Pernapasan Manusia Kelas V SDN Kebonsari 3 Malang. Jurnal Pendidikan: Teori, Penelitian, Dan Pengembangan, 1(6), 1120-1126. https://doi.org/10.17977/jp.v1i6.6456

Amelia, D. J., \& Saputra, S. Y. (2017). Analisis Kelayakan Buku Siswa Kelas IV Tema Makhluk Hidup Kurikulum 2013. Pedagogia: Jurnal Pendidikan, 6(1), 98-109. https://doi.org/10.21070/pedagogia.v6i1.617

Amrita, P. D., \& Kuswanto, H. (2019). Pengembangan Mobile Learning IPA Sasirangan Materi Pencemaran Lingkungan untuk Peserta Didik SMP. JTP-Jurnal Teknologi Pendidikan, 21(2), 151-164. https://doi.org/10.21009/jtp.v21i2.11446

Anugrahana, A. (2020). Hambatan, Solusi dan Harapan: Pembelajaran Daring Selama Masa Pandemi Covid-19 Oleh Guru Sekolah Dasar. Jurnal Scholaria, 10(3), 282-289. https://doi.org/10.24246/j.js.2020.v10.i3.p282-289

Astuti, I. A. D., Sumarni, R. A., \& Saraswati, D. L. (2017). Pengembangan Media Pembelajaran Mobile Learning Berbasis Android pada Materi Sifat Koligatif Larutan. Jurnal Penelitian \& Pengembangan Pendidikan Fisika, 3(1), 57-62. https://doi.org/10.21009/jrpk.072.10

Baharuddin, Indana, S., \& Koestiari, T. (2017). Perangkat Pembelajaran IPA Berbasis Inkuiri Terbimbing dengan Tugas Proyek Materi Sistem Ekskresi untuk Menuntaskan Hasil Belajar Siswa SMP. Jurnal IPA \& Pembelajaran IPA, 1(1), 81-97. https://doi.org/10.24815/jipi.v1i1.9574

Citrasmi, N. W., Wirya, N., \& Tegeh, I. M. (2016). Pengaruh Model Pembelajaran Scramble Berbantuan Media Gambar Terhadap Hasil Belajar IPA Di SD. Jurnal Mimbar PGSD Undiksha, 4(2). https://doi.org/10.23887/jjpgsd.v4i2.8425

Darmawan, H. (2014). Peningkatan Kreatifitas Mahasiswa Dalam Merancang Media Pembelajaran Multimedia IPA Berbasis Animasi Melalui Model Cooperative Learning. Jurnal Edukasi, 12(2), 193-204. https://doi.org/10.31571/edukasi.v12i2.155 
Diawati, L. P. (2018). Pengaruh Model Children's Learning in Scince Berbantuan Media Audio Visual Terhadap Kompetensi Pengetahuan IPA Siswa. Jurnal Mimbar Ilmu, 23(2), 113-121. https://doi.org/10.23887/mi.v23i2.16417

Egok, A. S., \& Hajani, T. J. (2018). Pengembangan Multimedia Interaktif pada Pembelajaran IPA bagi Siswa Sekolah Dasar Kota Lubuklinggau. Journal of Elementary School (JOES), 1(2), 141-157. https://doi.org/10.31539/joes.v1i2.446

Fitra, Nurhadi, \& Irawan. (2017). Perancangan Aplikasi Perangkat Ajar Pengenalan Anggota Tubuh Manusia Berbasis Android. Jurnal Ilmiah Media Processor, 9(1), 89-97.

Fitriyani, Y., Fauzi, I., \& Sari, M. Z. (2020). Motivasi Belajar Mahasiswa Pada Pembelajaran Daring Selama Pandemik Covid-19. Jurnal Kependidikan: Jurnal Hasil Penelitian Dan Kajian Kepustakaan Di Bidang Pendidikan, Pengajaran Dan Pembelajaran, 6(2), 165-175. https://doi.org/10.23917/ppd.v7i1.10973

Hanafy, M. S. (2014). Konsep Belajar dan Pembelajaran. Lentera Pendidikan, 17(1), 66-79. https://doi.org/10.24252/lp.2014v17n1a5

Irfan, I., Muhiddin, M., \& Ristiana, E. (2019). Pengembangan Media Pembelajaran IPA Berbasis Powerpoint di Sekolah Dasar. Indonesian Journal of Primary Education, 3(2), 16-27. https://doi.org/10.17509/ijpe.v3i2.21765

Khosiyah, M., \& Gunawan. (2019). Pengembangan Media Belajar Berbasis Android Pada Materi Tata Surya Untuk Siswa Sekolah Dasar. Elementa: Jurnal Pendidikan Guru Sekolah Dasar, 1(2), 168177. https://doi.org/10.33654/pgsd

Krissandi, A. D. S., \& Rusmawan, R. (2015). Kendala Guru Sekolah Dasar Dalam Implementasi Kurikulum 2013. Jurnal Cakrawala Pendidikan, 3(3), 457-467. https://doi.org/10.21831/cp.v3i3.7409

Londa, A. H., Mete, Y. Y., \& Sadipun, B. (2018). Penggunaan Media Puzzle untuk Meningkatkan Hasil Belajar Peserta Didik pada Pembelajaran IPA. Journal of Elementary School (JOES), 1(2), 113120. https://doi.org/10.31539/joes.v1i2.359

Mudanta, K. A., Astawan, I. G., \& Jayanta, I. N. L. (2020). Instrumen Penilaian Motivasi Belajar dan Hasil Belajar IPA Siswa Kelas V Sekolah Dasar. Mimbar Ilmu, 25(2), 101-109. https://doi.org/10.23887/mi.v25i2.26611

Mudarini, dkk H. (2017). Pengaruh Pembelajaran Student Facilitator And Explaining (SFAE) Berbantuan Media Kartu Terhadap Hasil Belajar IPA Siswa. Jurnal Mimbar PGSD Universitas Pendidikan Ganesha, 5(2), 1-11. https://doi.org/10.23887/jjpgsd.v5i2.11016

Mulyadin. (2016). Implementasi Kebijakan Pembelajaran Tematik Terpadu Kurikulum 2013 Di SDN Kauman 1 Malang Dan SD Muhammadiyah 1 Malang. Jurnal Edutama, 3(2), 31-48. https://doi.org/10.30734/jpe.v3i2.35

Ningsih, S., \& Adesti, A. (2019). Pengembangan Mobile Learning Berbasis Android pada Mata Kuliah Strategi Pembelajaran Universitas Baturaja. Edcomtech Jurnal Kajian Teknologi Pendidikan, 4(2), 163-172. https://doi.org/10.17977/um039v4i22019p163

Novitasari, D. (2016). Pengaruh Penggunaan Multimedia Interaktif Terhadap Kemampuan Pemahaman Konsep Matematis Siswa. FIBONACCI: Jurnal Pendidikan Matematika Dan Matematika, 2(2), 8. https://doi.org/10.24853/fbc.2.2.8-18

Nurhadi, \& Sobri, M. (2017). Pengembangan Media Pembelajaran IPA Berbasis Android dalam Meningkatan Kwalitas Pembelajaran Siswa SMA. Jurnal Ilmiah Betrik: Besemah Teknologi Informasi Dan Komputer, 8(3), 137-144. https://doi.org/10.36050/betrik.v8i03.74

Nurseto, T. (2011). Membuat Media Pembelajaran yang Menarik. Jurnal Ekonomi Dan Pendidikan, 8(1), 19-35. https://doi.org/10.21831/jep.v8i1.706

Permana, E. P., \& Nourmavita, D. (2017). Pengembangan Multimedia Interaktif Pada Mata Pelajaran IPA Materi Mendeskripsikan Daur Hidup Hewan di Lingkungan Sekitar Siswa Kelas IV Sekolah 
Dasar. Jurnal PGSD: Jurnal Ilmiah Pendidikan Guru Sekolah Dasar, 10(2), 79-85. https://doi.org/10.33369/pgsd.10.2.79-85

Putra, C. A. (2017). Pemanfaatan Teknologi Gadget Sebagai Media Pembelajaran. 2(2), 1-10. https://doi.org/10.33084/bitnet.v2i2.752

Putri, D. I., Isnanto, R. R., \& Martono, K. T. (2016). Perancangan Aplikasi Multimedia untuk Pembelajaran Anatomi Tubuh Manusia untuk Sekolah Dasar. Jurnal Teknologi Dan Sistem Komputer, 4(1), 124-132. https://doi.org/10.14710/jtsiskom.4.1.2016.124-132

Putria, H., Maula, L. H., \& Uswatun, D. A. (2020). Analisis Proses pembelajaran Dalam Jaringan (DARING) Masa Pandemi Covid-19 pada Guru Sekolah Dasar. Jurnal Basicedu, 4(4), 861-872. https://doi.org/10.31004/basicedu.v4i4.460

Qistina, M., Alpusari, M., Noviana, E., \& Hermita, N. (2019). Pengembangan Multimedia Interaktif Mata Pelajaran IPA Kelas IVC SD Negeri 034 Taraibangun Kabupaten Kampar. Primary: Jurnal Pendidikan Guru Sekolah Dasar, 8(2), 160-172. https://doi.org/10.33578/jpfkip.v8i2.7649

Saifudin, M., Susilaningsih, S., \& Wedi, A. (2020). Pengembangan Multimedia Interaktif Materi Sumber Energi untuk Memudahkan Belajar Siswa SD. JKTP: Jurnal Kajian Teknologi Pendidikan, 3(1), 68-77. https://doi.org/10.17977/um038v3i12019p068

Surahman, E. (2019). Integrated Mobile Learning System (Imoles) Sebagai Upaya Mewujudkan Masyarakat Pebelajar Unggul Era Digital. Jinotep (Jurnal Inovasi Dan Teknologi Pembelajaran) Kajian Dan Riset Dalam Teknologi Pembelajaran, 5(2), 50-56. https://doi.org/10.17977/um031v5i22019p050

Widayat, W., Kasmui, K., \& Sukaesih, S. (2014). Pengembangan Multimedia Interaktif Sebagai Media Pembelajaran Ipa Terpadu Pada Tema Sistem Gerak Pada Manusia. USEJ - Unnes Science Education Journal, 3(2), 535-541. https://doi.org/10.15294/usej.v3i2.3353

Widiana, I. W., Rendra, N. T., \& Wulantari, N. W. (2019). Media Pembelajaran Puzzle Untuk Meningkatkan Hasil Belajar Siswa Kelas IV pada kompetensi pengetahuan IPA. Indonesian Journal Of Educational Research and Review, 2(3), 354-362. https://doi.org/10.23887/ijerr.v2i3.22563 